\title{
PROGESTERONE CONCENTRATIONS IN MILK OF SUPEROVULATED COWS
}

\author{
E. KUDLÁC, J. KONEČNÝ and J. ČERMÁK
}

\begin{abstract}
Department of Obstetrics, Gynaecology and Andrology, University of Veterinary Science, 61242 Brno
\end{abstract}

Received fune 1, 1990

\begin{abstract}
Kudláč E., J. Konečný, J. Cermák: Progesterone Concentrations in Milk of Superovulated Cows. Acta vet. Brno, 60, 1991: 171 - 179.

Ovarian response of donor cows after the administration of PMSG was lower $(0-24$, average $4.36 \pm 5.65$ embryos) than after the administration of FSH (0-41, average $9.27 \pm 11.82$ embryos). Better results of the superovulation were observed - in donor cows with high levels of milk progesterone $(>5.0 \mathrm{ng} / \mathrm{ml})$ on the first day of the superovulatory stimulation and on the day of PGF2alpha administration than in cows with lower values or subsequent slow and insufficient drop in progesterone concentrations. Correlations were established between the numbers of corpora lutea, the number of embryos recovered and the level of progesterone in milk of donor cows superovulated by PMSG from day 4 after insemination and in the case of superovulation by FSH already from day 2 after insemination.

Milk progesterone concentration assays are useful to provide a substantial and fairly objective information on the level of the superovulatory response.
\end{abstract}

Cattle, superovulation, FSH, PMSG, ovarian response, progesterone

The transfer of embryos is becoming an integral part of a complex system of controlled reproduction in cattle. The method can be used to accelerate the breeding progress significantly and its application can be recommended in spite of considerable technical and financial problems involved. Procedures for practically all the necessary steps have been established and mastered, and generally good results are achieved in many countries (Hahn 1985, 1989; Greve 1986, inter alia), including Czechoslovakia (Holý 1988).

In the complex of problems related to embryo transfer, the decisive role is played by the effectivity and reliability of the superovulatory response and thus the number of transferable embryos is crucial. It should be noted, however, that in spite of an enormous effort. and extensive research work, the question of superovulation remains mostly unanswered and no examination procedure has been established that would allow an objective evaluation of suitable donor cows, which would guarantee a stable level of ovarian response and a constant recovery of a sufficient number of embryos.

It is a well-known fact that the level of superovulatory response and its final results characterized by the number of good-quality transferable embryos depend on the breed, age, nutrition and health, the conditions at the parturition, puerperium, sexual cycle and the immediate condition of the ovaries, the method of superovulation and the gonadotropin used, the method of embryo recovery, and also other factors (Greve 1982; Kudlác and Holý 1984; Majerčiak 1989, etc.).

Among the limiting factors for an accurate assessment of suitable donor cows and successful superovulation Holý (1988) includes a balanced metabolism, a regular pattern of the reproductive cycle, including fully functional corpora lutea, and a sufficient sensitivity of donor cows to the administered hormone.

A weaker response and frequently missing ovulation, together with low levels of progesterone in cows with metabolic disorders, particularly acidosis and ketosis, have already been demonstrated by our group (Vinkler et al. 1983; Kudláč et al. 1985). Most recently, we have been 


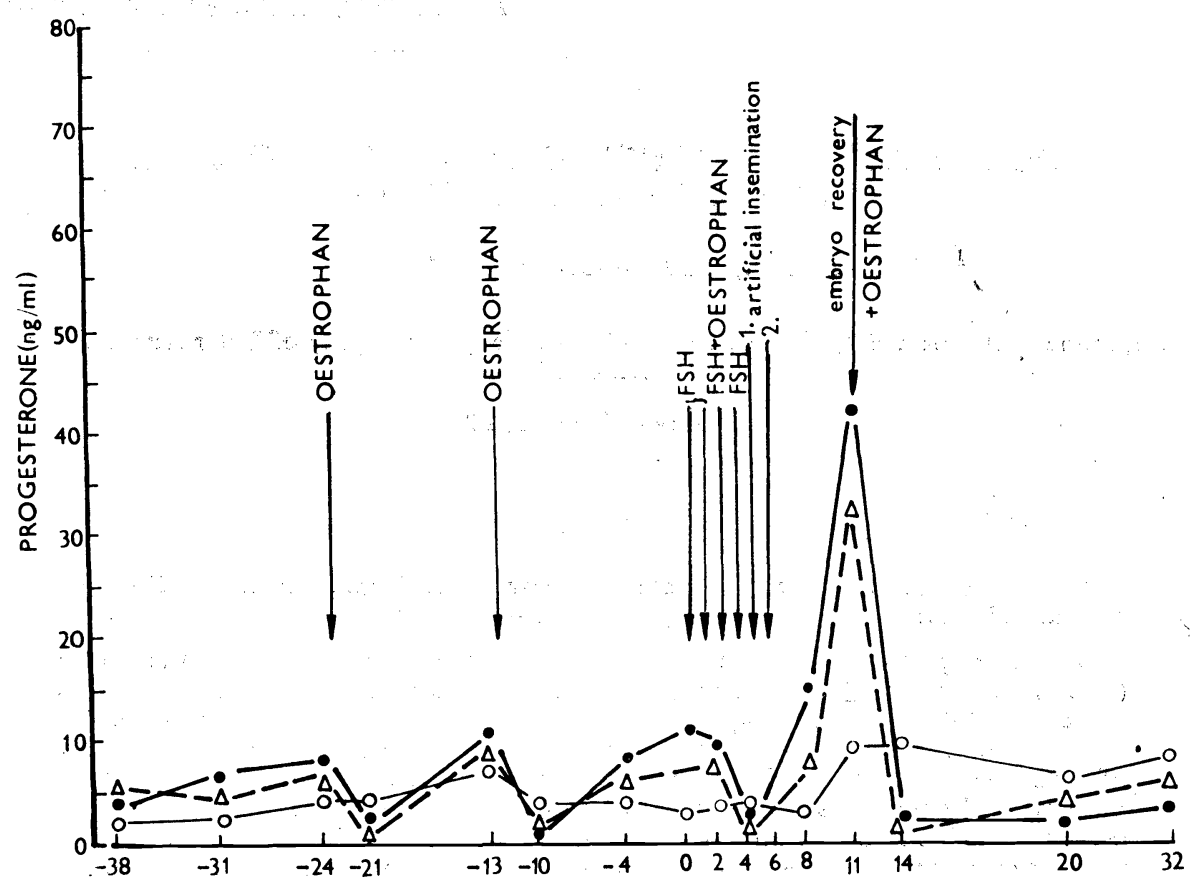

Fig. 1. Average progesterone levels in full milk of donor cows during and after superovulation in groups according to the number of corpora lutea (CL)

donors with 8-12 CL $\Delta---\Delta$

$0-0$

donors with $4-7 \mathrm{CL}$

donors with lower response

able to confirm (Vinkler et al. 1990; Kudláč 1990) more frequent variations of ovulation and lower levels of progesterone in cows subjected to an acidotic condition when superovulated by PMSG.

The relationship between milk progesterone concentrations and the results of superovulation were studied by Elsaesser et al. (1981), Greve (1982), Pícha et al. (1984), Saumande et al. (1985) Kweon (1987), Goto et al. (1987), inter alia. Reports on the progesterone concentrations before superovulation and their relation to its results are less numerous (Kitzig et al. 1986, Allen and Foote 1987).

The purpose of our work was to study the development of progesterone concentrations in donor cows before and after superovulation and to determine the relation between the progesterone concentrations and the results of superovulation.

\section{Materials and Methods}

The concentrations of progesterone were studied in two groups of cows before and after the superovulatory treatment. The aim was to ascertain to what extent this method provides objective criteria for the selection of donor cows and checking of the superovulatory response.

In the first group consisting of 45 cows, progesterone levels were estimated by RIA in fat-free milk (Hruška et al., 1978). FSH (Folicotropin inj. Spofa) and PMSG (Bioveta Ivanovice na Hané) were used as stimulants, in some cases anti-PMSG serum (Antisergon, Bioveta Ivanovice na Hané) was also used. In the second group (54 animals) progesterone was determined by RIA in full milk (Píchová et al, 1977) and superovulation was initiated by FSH (Folicotropin inj. Spofa) 


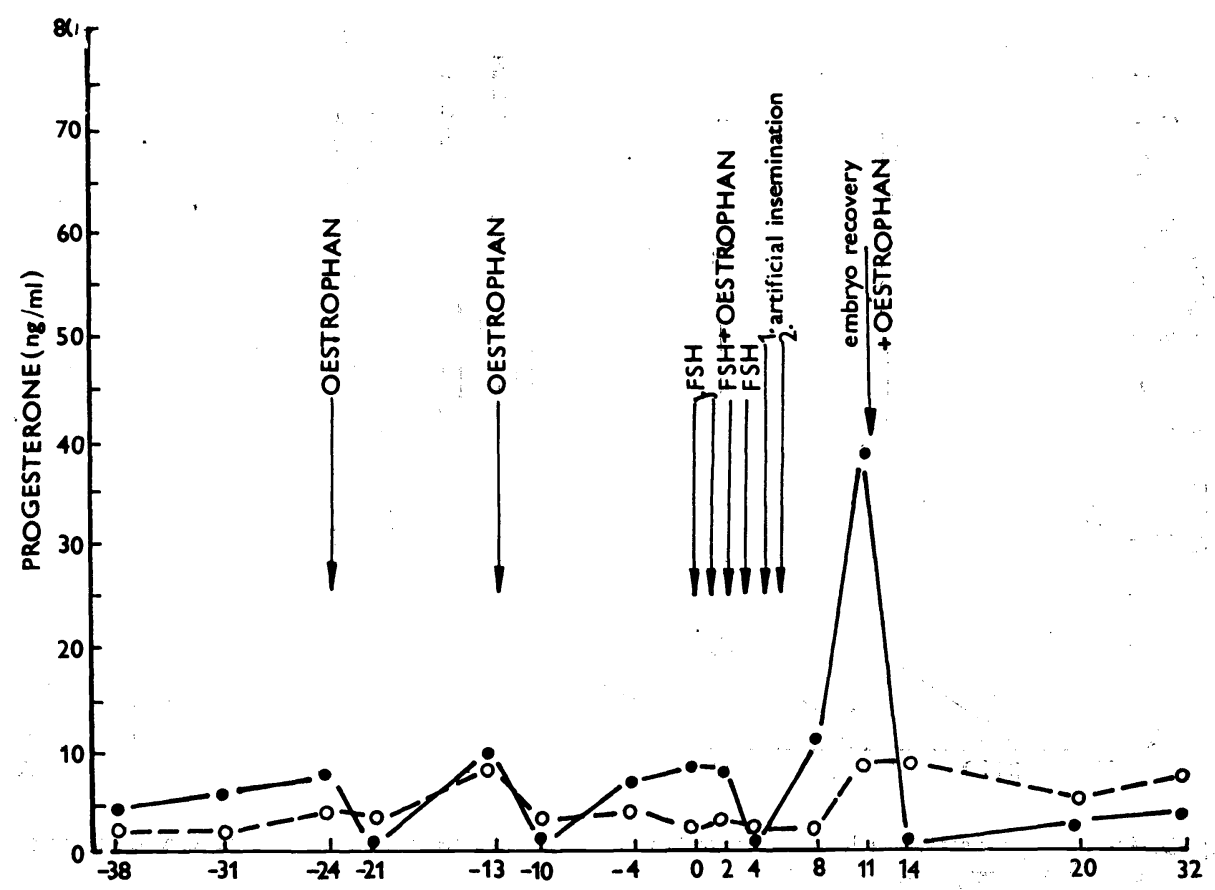

Fig. 2. Average progesterone levels in full milk of donor cows during and after superovulation in groups according to the number of corpora lutea (CL)

$-1-0$

donors with $4-12 \mathrm{CL}$
$0--0$

donors with $1-3 \mathrm{CL}$

only: The administration of hormones in combination with PGF2 alpha was carried out in accordance with standard methods used in Czechoslovakia (Kudlá č and Holý 1984), usually afterer once or twice induced luteolysis. The relation between the progesterone concentrations on the separate days before and particularly after the superovulatory treatment and the results of the superovulation was statistically, evaluated using the sequence correlation by Spearman (Reisenauer 1970).

\section{Results and Discussion}

While the differences in progesterone levels in individual cows prior to superovulatory treatment were relatively very large, the results nevertheless provided a good information on the character of the cycle and particularly on the activity of corpora lutea. The response to the superovulatory treatment was more constant in cows where progesterone levels corresponded to a normal oestrous pattern and a fully functional corpus luteum. However, no significant relation was demonstrated between the progesterone concentrations prior to or at the beginning of the superovulatory treatment and the quantitative or qualitative features of the superovulatory response (the number of ovulated follicles and developing corpora lutea), although certain trends were clearly discernible (Figures 1 and 2). Generally speaking, the results of the superovulation assessed according to the number of corpora lutea and the embryos recovered varied greatly both 


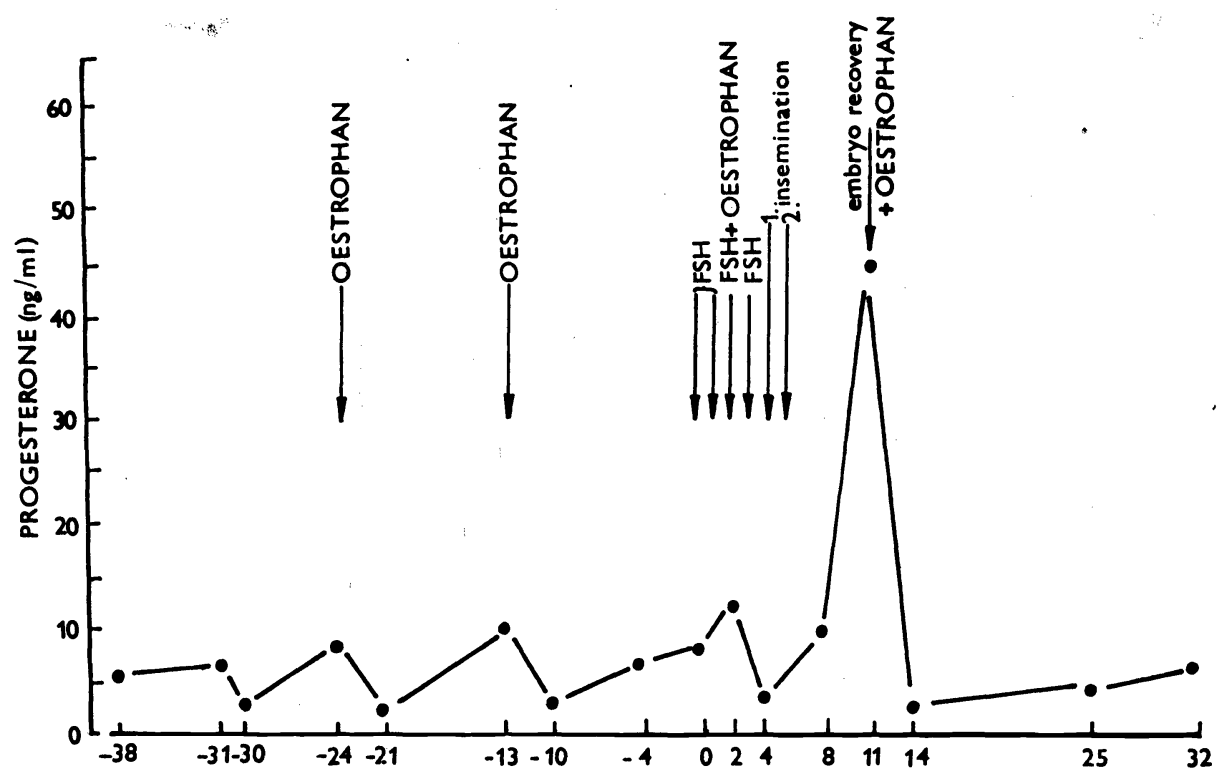

Fig. 3. Average progesterone levels in cow No. 16105 with four subsequent superovulations and a constant response

among individual cows and among individual superovulatory treatments in the same cow. Progesterone level assay was found to be a highly objective method of monitoring luteolysis after PGF2alpha administration (Figures 1 and 2). A clearly significant relation (Tables 1 to 4) was ascertained in both groups of cows between progesterone levels and the superovulatory response (the number of corpora lutea or the number of embryos recovered). In donor cows treated with PMSG, the relation was found significant on the day after insemination $(P<0.05)$ and highly significant on day $6(\mathrm{P}<0.01)$. When FSH was administered, the relation was found significant on day 2 after insemination and highly significant on day 3 to $4(\mathrm{P}<0.01)$.

In the second group of cows, milk progesterone concentrations before and after superovulation were assessed with regard to the success of superovulation. Progesterone concentrations of $5.0 \mathrm{ng}$ or more in $1 \mathrm{ml}$ milk in the luteal phase with fully functional corpora lutea were considered normal, while lower concentrations were regarded as deviations. At the beginning of the luteal phase (day 4 after oestrus) and on the day of oestrus, concentrations of $3 \mathrm{ng} / \mathrm{ml}$ or more and $0-2 \mathrm{ng} / \mathrm{ml}$ progesterone respectively, and at least $20 \mathrm{ng} / \mathrm{ml}$ in cows with a good superovulatory response were considered normal. The correlation between the percentage of cows with progesterone level deviations and the success rate of superovulatory treatment is shown in Tab. 5. Cows with the least response which were not even flushed, showed highest deviations in progesterone concentrations on nearly all days of the assessment, while the percentage of deviations in cows with a good ovarian response and the largest yield of viable embryos was minimal (Tab. 6). An individal evaluation of the relation between progesterone levels at and after the beginning of the superovulatory treatment and its results showed that the most 
Table 1

Evaluation of the Relation between Progesterone Levels and the Number of Corpora lutea by Means of Sequence Correlation Test after Spearman (Group 1)

\begin{tabular}{|c|c|c|c|c|c|c|}
\hline \multirow{2}{*}{\multicolumn{2}{|c|}{ Superovulation }} & \multirow{2}{*}{$\begin{array}{c}\text { Onset of } \\
\text { Superovulation } \\
\text { (Day 0) }\end{array}$} & \multicolumn{4}{|c|}{ Before, During and After Insemination } \\
\hline & & & D 4-D 5 & D 7 & D 8 & D 9-D 10 \\
\hline $\begin{array}{l}\text { Serum } \\
\text { Gonadotrophin }\end{array}$ & $\begin{array}{l}\mathbf{n} \\
\mathbf{r} \\
\mathbf{t} \\
\mathbf{P}\end{array}$ & $\begin{array}{l}22 \\
0.504 \\
2.607 \\
+\end{array}$ & $\begin{array}{c}22 \\
0.421 \\
2.075 \\
-\end{array}$ & $\begin{array}{l}\times \\
\times \\
\times \\
\times\end{array}$ & $\begin{array}{c}14 \\
0.647 \\
2.941 \\
+\end{array}$ & $\begin{array}{l}11 \\
0.766 \\
3.574 \\
+++\end{array}$ \\
\hline FSH & $\begin{array}{l}\mathbf{n} \\
\mathbf{r} \\
\mathbf{t} \\
\mathbf{P}\end{array}$ & $\begin{array}{l}23 \\
0.343 \\
1.671 \\
-\end{array}$ & $\begin{array}{c}23 \\
0.022 \\
1.102 \\
-\end{array}$ & $\begin{array}{l}23 \\
0.698 \\
4.465 \\
+++\end{array}$ & $\begin{array}{l}23 \\
0.740 \\
5.040 \\
+++\end{array}$ & $\begin{array}{l}16 \\
0.742 \\
4.414 \\
+++\end{array}$ \\
\hline
\end{tabular}

Kev: n number of animals

r Spearman's correlation coefficient

$t$ significance of relation

$\times$ not monitored
- N.S. not significant

$+\mathbf{P}<0.05$

$++\mathbf{P}<0.01$

Table 2

Evaluation of the Relation between Progesterone Levels and the Number of Embryos Recovered by Means of Sequence Correlation Test after Spearman (Group 1)

\begin{tabular}{|c|c|c|c|c|c|c|}
\hline \multirow{2}{*}{\multicolumn{2}{|c|}{$\begin{array}{l}\text { Superovulation } \\
\text { Treatment }\end{array}$}} & \multirow{2}{*}{$\begin{array}{c}\text { Onset of } \\
\text { Superovulation } \\
\text { (Day 0) }\end{array}$} & \multicolumn{4}{|c|}{ Eefore, During and After Insemination } \\
\hline & & & D 4 & D 7 & D 8 & D 10 \\
\hline $\begin{array}{l}\text { Serum } \\
\text { Gonadotrophin }\end{array}$ & $\begin{array}{l}\mathbf{n} \\
\mathbf{r} \\
\mathbf{t} \\
\mathbf{P}\end{array}$ & $\begin{array}{c}22 \\
0.538 \\
2.851 \\
+++\end{array}$ & $\begin{array}{c}22 \\
0.263 \\
2.075 \\
-\end{array}$ & $\begin{array}{l}x \\
\times \\
x \\
x\end{array}$ & $\begin{array}{c}74 \\
0.548 \\
2.271 \\
+\end{array}$ & $\begin{array}{c}11 \\
0.477 \\
1.629 \\
-\end{array}$ \\
\hline FSH & $\begin{array}{l}\mathbf{n} \\
\mathbf{r} \\
\mathbf{t} \\
\mathbf{P}\end{array}$ & $\begin{array}{c}23 \\
0.254 \\
1.202 \\
-\end{array}$ & $\begin{array}{c}23 \\
0.334 \\
1.621 \\
-\end{array}$ & $\begin{array}{c}23 \\
0.687 \\
4.330 \\
+++\end{array}$ & $\begin{array}{c}23 \\
0.715 \\
4.689 \\
+++\end{array}$ & $\begin{array}{c}16 \\
0.893 \\
7.410 \\
+++\end{array}$ \\
\hline
\end{tabular}

Key: $n$ number of animals

r Spearman's correlation coefficient

$t$ significance of relation

$x$ not monitored
- N.S.

$+\mathbf{P}<0.05$

$+++\mathbf{P}<0.01$

standard results were found in the donor cow No. 16105 (Fig. 3). This is a very good dairy cow with a regular sexual cycle, stabilized function of the corpus luteum and progesterone production, moreover with a regularly occurring onset of new fully functional cycle after each flushing and administration of PGF2alpha. Much better ovulation rate and more constant character of ovarian response were found after the administration of FSH than after PMSG. The average number of embryos recovered from 22 cows in the first group treated with PMSG was $4.36 \pm 5.65$ (min. 0 and max. 24) and $9.22 \pm 11.82$ (min. 0 and max. 41) from 23 cows treated with FSH. On average 6.2 embryos were recovered per donor in the second group.

Our investigations support the opinion that pituitary FSH can produce more constant results in superovulation than the administration of PMSG. The highly standard character of the superovulatory response of some donors is probably determined by a large number of internal and external factors, mainly the firm constitution and a high stability of the neuroendocrine system. The final superovulatory effect achieved in our study is comparable to the data by other authors 
Table 3

Evaluation of the Relation between Progesterone Levels and the Number of Corpora Iutea by Means of Sequence Correlation Test after Spearman (Group 2)

\begin{tabular}{|c|c|c|c|c|c|c|}
\hline \multirow{2}{*}{$\begin{array}{l}\text { Superovulation } \\
\text { Treatment }\end{array}$} & \multirow{2}{*}{$\begin{array}{c}\text { Onset of } \\
\text { Superovulation } \\
\text { (day 0) }\end{array}$} & \multicolumn{5}{|c|}{ Before, During and After Insemination } \\
\hline & & D 2 & D 4 & & D $7-8$ & $\mathrm{D} 10-11$ \\
\hline $\begin{array}{r}\text { FSH } \\
\\
\\
\\
\\
\\
\mathbf{r} \\
\mathbf{p}\end{array}$ & $\begin{array}{l}36 \\
0.650 \\
5.138 \\
+++\end{array}$ & $\begin{array}{c}34 \\
0.734 \\
6.295 \\
+++\end{array}$ & $\begin{array}{l}37 \\
0.735 \\
2.458 \\
++\end{array}$ & 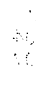 & $\begin{array}{l}33 \\
0.768 \\
6.886 \\
+++\end{array}$ & $\begin{array}{c}50 \\
0.713 \\
7.190 \\
+++\end{array}$ \\
\hline
\end{tabular}

Table 4

Evaluation of the Relation between Progesterone Levels and the Number of Embrya Recovered by Means of Sequence Correlation Test after Spearman (Group 2)

\begin{tabular}{|c|c|c|c|c|c|c|}
\hline \multirow{2}{*}{\multicolumn{2}{|c|}{$\begin{array}{l}\text { Superovulation } \\
\text { Treatment }\end{array}$}} & \multirow{2}{*}{$\begin{array}{l}\text { Onset of } \\
\text { Superovulation } \\
\text { (day 0) }\end{array}$} & \multicolumn{4}{|c|}{ Before, During and After Insemination } \\
\hline & & & D 2 & D 4 & D 7-8 & D $10-11$ \\
\hline FSH & $\begin{array}{l}\mathbf{n} \\
\mathbf{r} \\
\mathbf{t} \\
\mathbf{P}\end{array}$ & $\begin{array}{c}36 \\
0.596 \\
4.451 \\
+++\end{array}$ & $\begin{array}{c}34 \\
0.700 \\
5.713 \\
+++\end{array}$ & $\begin{array}{r}37 \\
\quad 0.384 \\
2.530 \\
++ \\
\\
\end{array}$ & $\begin{array}{c}33 \\
0.750 \\
6.519 \\
+++\end{array}$ & $\begin{array}{c}50 \\
0.611 \\
5.457 \\
+++\end{array}$ \\
\hline
\end{tabular}

Key: n number of animals $++\mathbf{P}<0.05$

$$
\begin{aligned}
& \mathbf{r} \\
& +++\quad \mathbf{P}<0.01
\end{aligned}
$$

Table 5

Relation Between Results of Superovulation in Cows and Progesterone Level on the Day of FSH Administration (total n $=38$, Group 2)

\begin{tabular}{|c|c|c|c|c|c|c|c|c|}
\hline \multirow{2}{*}{$\begin{array}{l}\text { Progesterone } \\
\text { Concentration }\end{array}$} & \multicolumn{2}{|c|}{ Donors Investigated } & \multicolumn{2}{|c|}{ Flushed } & \multicolumn{2}{|c|}{ Embryos Recovered } & \multicolumn{2}{|c|}{$\begin{array}{c}\text { Transferable } \\
\text { embryos }\end{array}$} \\
\hline & $\mathrm{n}$ & $\%$ & $\mathbf{n}$ & $\%$ & $\mathbf{n}$ & $\%$ & $\mathbf{n}$ & $\%$ \\
\hline $\begin{array}{l}\text { Above } 5.0 \mathrm{ng} / \mathrm{ml} \\
\text { Below } 5.0 \mathrm{ng} / \mathrm{ml}\end{array}$ & $\begin{array}{l}24 \\
14\end{array}$ & $\begin{array}{l}63.16 \\
36.84\end{array}$ & $\begin{array}{r}23 \\
6\end{array}$ & $\begin{array}{l}95.83 \\
42.86\end{array}$ & $\begin{array}{r}21 \\
5\end{array}$ & $\begin{array}{r}87.50 \\
35.71\end{array}$ & $\begin{array}{r}20 \\
3\end{array}$ & $\begin{array}{l}88.33 \\
21.43\end{array}$ \\
\hline
\end{tabular}

\begin{tabular}{|c|c|c|c|c|c|c|}
\hline \multirow{2}{*}{$\begin{array}{l}\text { Progesterone } \\
\text { Concentration }\end{array}$} & \multicolumn{2}{|c|}{$\begin{array}{c}\text { Number of Corpora } \\
\text { Lutea Per Donor }\end{array}$} & \multicolumn{2}{|c|}{$\begin{array}{l}\text { Number of Embryos } \\
\text { Recovered Per Donor }\end{array}$} & \multicolumn{2}{|c|}{$\begin{array}{l}\text { Numbers of Transfer- } \\
\text { able Embryos Per Donor }\end{array}$} \\
\hline & Stimulated & Flushed & Stimulated & Flushed & Stimulated & Flushed \\
\hline $\begin{array}{l}\text { Above } 5.0 \mathrm{ng} / \mathrm{ml} \\
\text { Below } 5.0 \mathrm{ng} / \mathrm{ml}\end{array}$ & $\begin{array}{l}8.13 \\
3.64\end{array}$ & $\begin{array}{l}8.39 \\
7.00\end{array}$ & $\begin{array}{l}6.25 \\
2.07\end{array}$ & $\begin{array}{l}6.52 \\
4.83\end{array}$ & $\begin{array}{l}3.67 \\
1.14\end{array}$ & $\begin{array}{l}3.83 \\
2.66\end{array}$ \\
\hline
\end{tabular}

Table 6

Percentage of Cows with Deviations in Progesterone Concentrations on Various Days prior to Superovulation

\begin{tabular}{|c|c|c|c|c|c|}
\hline \multirow{2}{*}{ Donor Group } & \multicolumn{5}{|c|}{$\begin{array}{c}\text { Percentage of Donors with Deviations in Progesterone Concentration } \\
\text { on Day } 0 \text { to Day } 11\end{array}$} \\
\hline & D 0 & D 2 & D 4 & D 8 & D 11 \\
\hline $\begin{array}{l}\text { Not Flushed } \\
\text { Flushed Without } \\
\text { Recovering Transferable } \\
\text { Embryos } \\
\text { Flushed with Recovering } \\
\text { Transferable Embryos }\end{array}$ & $\begin{array}{l}50.00 \\
13.04\end{array}$ & $\begin{array}{l}83.33 \\
21.05\end{array}$ & $\begin{array}{l}0 \\
0\end{array}$ & $\begin{array}{r}75.00 \\
38.10\end{array}$ & $\begin{array}{r}50.00 \\
9.09\end{array}$ \\
\hline
\end{tabular}


both in Czechoslovakia and in other countries (Monniaux et al. 1983; Hahn 1985; Greve 1986; Baumung 1986; Krontorád et al. 1986; Holý 1985, 1987; Majerčiak 1989, inter alia).

A critical review of our results and the data published by many other authors (Kitzig et al. 1984; Kweon et al. 1986; Yadav et al. 1986; Goto et al. 1987, inter alia) suggest that the assessment of milk progesterone concentrations in cows before and after superovulation is very effective and can serve as an important secondary criterion in the final selection of donor cows for the stimulation and as a valuable source of information for the assessment of the ovarian response to superovulatory treatment performed. We confirmed the data by Elsaesser (1981), Greve (1986), Callessen et al. (1986), Stubbings and Walton (1986), Yadav et al. (1986) that low levels of milk progesterone in cows on the first day of a superovulatory treatment indicate poor results of superovulation even though the presence of the corpus luteum on the ovary may be clearly demonstrated.

\section{Hladina progesteronu v mléce superovulovaných krav}

Ovariální odezva krav - dárkyň byla při použití sérového gonadotropinu nižší $(0-24$ tj. $\Sigma=4,36 \pm 5,65$ získaných embryí) než při použití $F S H(0-41$ tj. $\varepsilon=9,27 \pm 11,82$ získaných embryí). $U$ dárkyñ s vysokou hladinou progesteronu $\mathrm{v}$ mléce $(>5.0 \mathrm{ng} / \mathrm{ml}) \mathrm{v}$ den superovulačního ošetření a $\mathrm{v}$ den aplikace $\mathrm{PGF}_{2}$ alfa byly zjištěny lepší výsledky superovulace než u krav s nižší hodnotou, respektive u krav s následným pomalým a nedostatečným poklesem progesteronu. Byly prokázány korelace mezi počtem žlutých tělísek a získaných embryí a hladinou progesteronu v mléce dárkyň superovulovaných sérovým gonadotropinem od 4. dne po inseminaci, při superovulaci FSH již od 2. dne po inseminaci.

Stanoveni hladin progesteronu částečně objektivizuje a velmi dobře informuje o úrovni dosažené superovulačni odezvy.

\section{Уровень прогестөрона в молоке сүперовулированных коров}

Овариальный отклик коров-доноров был при использовании сывороточного гонадотропина ниже $(0-24$, т. е. $\Sigma=4,36 \pm 5,65$ полученных эмбрионов), чем при применении FSH (0-41, т. е. $\Sigma=9,27 \pm 11,82$ полученных эмбрионов). У доноров с высоким уровнем прогестерона в молоке $(>5,0 \mathrm{Hr} / \mathrm{mn})$ в период сүперовуляционного исследования и применения $\mathrm{PGF}_{2}$-альфа были выявлены результаты овуляции лучше, чем у коров с более низкой или у коров с последовательным медленным и недостаточным понижением прогестерона. Была выявлена корреляция между численностью желтых тел и полученных эмбрионов и уровнем прогестерона в молоке доноров, суперовулированных сывороточным гонадотропином начиная с 4 суток после осеменения, при суперовуляции FSH уже со 2 суток после осеменения.

Определение уровня прогестерона является частичной объективизацией и весьма хорошей информацией об уровне достигнутого суперовуляционного ответа. 


\section{References}

ALLEN, S. E.-FOOE, R. H.: Aiding a bovine embryo transfer program with an enzyme linked immunoadsorbent assay for progesterone. Theriogenology, 27, 198: 202-211

BAUMUNG, A.: Die züchterische Nutzung des Embryotransfers zur Erweiterung des Reproduktionspotentiales und der Selektionintensität. Tagungsbericht d. Akademie der Landwirtschafswissenschaften DDR, 242, 1986: 73-82

CALLESEN, H.-GREVE, T.-HYTTEL, P.: Preovulatory endocrinology and oocyte maturation in superovulated cattle. Theriogenology, 25, 1986: 71-86.

ELSSAESSER, P.-SACHER, B.-HAUPT, P.-SCHUZBAR, W.-SCHMIDT, D.: Relationship between the concentration of progesterone in milk and ovarian response to suplementation treatment in the cow. Zuchthyg., 16, 1981: 193-200

GOTO, K. - NAKANISHI, Y,-OHKUTSU, S. - OGAWA, K. - TASAK, M. - OHTA, M. INOHAE, S. - TATAYANE, S. - KAWABATA, T: Plasma progesterone profiles and embryo quality in superovulated Japanese Black cattle. Theriogenology, 27, 1987:819-826

GREVE, T.: Embryo transplantation in dairy cattle. An attempt to analyse factors that may affect embryo number and quality. Annecy, France, 1982: 251-276

GREVE, T.: Practical aspects of embryo transplantation in cattle. Brit. Vet. J., 142, 1986: 228-231

HAHN, J.: Möglichkeiten und Grenzen des Embryotransfers (ET) in der tierärztlichen Praxis. Prakt. Tierarzt, 66, 1985: 123-125

HAHN, J.: Embryotransfer beim Rind als Durchführung von MOET-Programmen. Ref. 36. intern. Fachtagung in Wels, Österreich, 1989: 1-14

HOLÝ, L. et al.: Ovulace, vajíčko jeho vlastnosti a oplození. Project Report VI-5 -3/07. Univ. of Vet. Science Brno, 1985: $60 \mathrm{p}$.

HOLYY, L.-LOPATÁROVA, M.-VAŇATKA, F.-CAHEL, F. - JIRICEK, A. - MAZUREK, J. - KADĚRA, J. - KLIMEŚ, V. - KRONTORÁD, P. - KROUPA, L. - HERMÁNEK, J.: Výsledky nechirurgického transferu embryí u skotu v chovatelské praxi. Vet. Med. (Praha), 32, 1987: 643-653

HOLY, L.: Embryotransfer jako významná metoda řízené reprodukce a chovatelské praxe. Abstrakty ze semináře 8. XI. 1988 v Ceských Heřmanicích, 1988: 1-9

HRUSKKA, K.: Radioimunoanalýza progesteronu v mléce. Project Report P-09329-251-03-01, VƯVL Brno, 1978, $121 \mathrm{p}$.

KITZIG, M.-KANITZ, W.-BLODOW, G.-SCHNEIDER, F.-REHBOCK, F.-ROMMEL, P.: Progesteronbestimmung zur Auswahl von Donoren beim Embryotransfer Rind. Mh. Vet. - Med., 41, 1986: 728-732

KRONTORAD, P.-HOLÝ, L.-LOPATÁROVÁ, M.-ROHA, V. - SPLICHAL, M.-HOLUB, J.: Embryotransfer jako významná součást rízené reprodukce skotu. Veterinářství, 36, 1986: 255-257

KUDLÁC, E.-HOLÝ, L.: Ŕizení a kontrola reprodukce ve velkochovech skotu. SZN Praha, 1984, 349 p.

KUDLÁC, E. a kol.: Pohlavní funkce u krav po porodu a jejich ovlivňování. Project Report VI- 5- 3/9, Univ. of Vet. Science Brno, 1985, $40 \mathrm{p}$.

KUDLÁC, E.: Vztah metabolických poruch $\mathrm{k}$ reprodukci a efektivnosti biotechnických metod. Sborník k 70. výročí založení buiatriky na VŠV Brno, Brno, 1990 (in press)

KWEON, O. K. -KANAGAWA, H. - TAKAHASHI, Y. - MIYAMOTO, Y. - MASAKI, J. UMEZU, M. - KAGABU, S. -IWAZUMI, Y.-ADYABI, Y.: Plasma endocrine profiles and cholesterol levels in superovulated cows. Theriogenology, 27, 1984: $841+857$

MEJERCIAK, M.: Veterinárno-farmakologické a hygienické zabezpečenie prenosu embryí hovädzieho dobytka. $\mathrm{PhD}$. Thesis, VŠV Košice, 1989: 159 p.

MONINIAUX, D.-CHUPIN, D.-SAUMANDE, J.: Superovulatory response of cattle. Theriogenology, 19, 1983: 55-81

PfCHA, J. - BARCIKOWSKI, B.-PICHOVÁ, D.-MfKA, D.-OLŠ, T.: Účinnost séra březích klisen na luteální tkáně skotu. Vet. Med. (Praha), 29, 1984: 465-472

PfCHOVÁ, D.-STUPNICKI, J.-PICHA, J. - PILZ, Z. - KULA, E.-PÖSCHL, M.: Kontrola estru a fertilní inseminace pomocí radioimunologického stanovení progesteronu $\mathrm{v}$ mléce. Project Report, ŽV-PVI-2-01, VƯŽV, Uhř něves, 1977: 283 p.

REISENAUER, R.: Metody matematické statistiky a jejich aplikace v technice. SNTL, Praha, 1970: 182 p.

SAUMANDE, J.-TAMBOURA, D.-CHUPIN, D.: Changes in milk and plasma concentrations of progesterone in cows after treatment to induce superovulation and their relationship with number of ovulations and embryos collected. Theriogenology, 23, 1985: 719-731

STUBBINGS, R. B. - WALTON, J. S.: Relationship between plasma progesterone concentra- 
tions and pregnancy rates in cattle receiving either fresh or previously frozen embryos. Theriogenology, 26, 1986: 145-155

VINKLER, A. - KUDLÁC, E.-KOZUMPLfK, J. -DANČfK, A.-DVORÁ, R. - VAŇATKA, F. - HRIVNÁK, J. - HOŠEK, L. Faktory ovlivňující výtěžnost př́ípravy dárců a př́iemců v programu přenosu raných embryí. Abstracts „O reprodukci hosp. zvírat" , VŠV, Brno, 1983: 45 VINKLER, A. - DVOŘAK, R. -ZENDULKA, I. - KUDLÁC, E.: Ovariální odpověđ a koncepční schopnost krav při acidóze vyvolané kyselinou octovou. Vet. Med. (Praha), 1990 (in press) YADAV, M. C. - WALTOK, J. S. - LESLIE, K. E.: Plasma concentration of luteinising hormone and progesterone during superovulation of dairy cows using follicle stimulating hormone and pregnant mare gonadotrophin. Theriogenology, 26, 1986: 523-540 